\section{Experiments on Animals}

The Research Defence Society has issued a brief note entitled Experiments on Animals and the Cruelty to Animals Act, 1876 (Pp. 4. London: Research Defence Society, 1963), designed to act as a guide to the present state of the law and of administrative practices at a time when the Home Secretary has decided to set up a departmental committoe to inquire whether any modifications of the law are required. This note sets out very briefly the general system hitherto in operation to ensure that there are no abuses in work undertaken according to existing rules. There has been considerable increase in the amount of work done on experimental animals in recent years and two additional inspectors are to be appointed by the Home Office. The suggestion has been made that the inspectors might be veterinary surgeons with the necessary special experience for the duties to be undertaken.

\section{Origin and Descent of Domestic Animals}

The late Shimon Angress, son of a Jewish family in Germany, escaped from the Nazis while a youth and reached Israel, where he managed to educate himself, and eventually obtained an M.S. degree in zoology at Chicago. Developing a great interest in the origins of domestic animals, he started a museum collection, accumulated much information about domestic animals, tamed wild animals and acquired a following of young peoplo at a centre in Israel. He died in 1958. An annotated bibliography on the origin and descent of domestic animals, covering the period 1900-55, has been published under the names of Shimon Angress and Charles A. Reed (Chicago Natural History Museum. Fieldiana Anthropology, 54, No. 1. An Annotated Bibliography on the Origin and Descent of Domestic Mammals, i200-1955. Pp. 143. Chicago: Natural History Museum, 1962. 2.75 dollars). This is a useful select bibliography of some 400 references, together with abstracts, arranged alphabetically under the names of authors.

\section{Sheep Husbandry and Research}

A BIBLIOGRAPHY of sheep husbandry and research, covering the period 1939-61, gleaned from a list of 31 British journals, has recently been issued by the National Sheep Breeders' Association. (Sheep Husbandry and Research: a Bibliography. Pp. 186. Radlett: National Sheep Breeders' Association: 1963. 15s.) It covers more than 1,200 references and was compiled by Dr. E. Cresswell, the Rowett Research Institute, Aberdeen. The matter is set out by titles under the names of the journals, seriatim, and subjects are not indicated, except from a routine search of the publication. Most of the references are included in Index Veterinarius and are placed under both author and subject headings and are easily found. A reason given for the present publication is the absence of any ready means of knowing what research and experiment were in progress. Perhaps some amplification of the systems of disseminating information adopted by the Commonwealth Burcau of Animal Health, Weybridge, might be followed to advantage for some other agricultural subjects. The great labour in finding particular subject-matter in this (titles only) bibliography covering only a very narrow range of publications and of titles would indicate the need to find means for providing readers with the information they may require.

\section{The Night Sky in June}

FulL moon occurs on June 7 d. 08h. 31m. U.T. and new moon on June $21 \mathrm{~d}$. $11 \mathrm{~h} .46 \mathrm{~m}$. The following conjunctions with the Moon take place: June 12d. 15h., Saturn $2^{\circ}$ N.; June 16d. 07h., Jupiter $4^{\circ} \mathrm{N}$.; June 26d. 19h., Mars $3^{\circ} \mathrm{S}$. In addition to these conjunctions with the Moon, Mars is in conjunction with Regulus on June 1d. 05h., Mars being $1^{\circ}$ N., Mercury with Venus on June 9d. 07h., Mercury being $3^{\circ} \mathrm{S}$., Venus with Aldebaran on June 21d. 01h., Venus being $5^{\circ}$ N., Mercury with Aldebaran on June 22d. 16h., Mercury being $3^{\circ}$ N., and Mercury with Venus on June $28 \mathrm{~d}$. $01 \mathrm{~h}$., Mercury being $0 \cdot 6^{\circ} \mathrm{S}$. Mercury and Venus are too close to the Sun for easy observation. Mars sets at $0 \mathrm{~h} .40 \mathrm{~m} ., 0 \mathrm{~h} .00 \mathrm{~m}$. and $23 \mathrm{~h} .10 \mathrm{~m}$. on June 1,15 and 30 , respectively. It is at a distance of 150 million miles on June 15, when its stellar magnitude is $+1 \cdot 3$; it is in Leo. Jupiter rises at $1 \mathrm{~h} .50 \mathrm{~m} ., 0 \mathrm{~h} .55 \mathrm{~m}$. and $0 \mathrm{~h} .00 \mathrm{~m}$. at the beginning, middle and end of the month, respectively. It is in Pisces, its stellar magnitude is -1.9 and its distance from the Earth on June 15 is 490 million miles. Saturn rises at $0 \mathrm{~h} .20 \mathrm{~m} ., 23 \mathrm{~h} .30 \mathrm{~m}$. and $22 \mathrm{~h}$. $25 \mathrm{~m}$. on June 1,15 and 30 , respectively. It is in Capricornus, its stellar magnitude is $+0 \cdot 6$ and its distance from the Earth on June 15 is 870 million miles. There is one occultation of a star brighter than magnitude 6 visible at Greenwich: June 2d. 23h. $17 \cdot 4 \mathrm{~m}$., 80 Vir. (disappearance). The summer solstice occurs on June 22d. $03 \mathrm{~h}$.

\section{Announcements}

Dr. R. C. Sutcliffe, director of research of the British Meteorological Office, has been awarded the International Meteorological Organization Prize. The Prize is one of the major honours of the meteorological world and is awarded for outstanding work in meteorology and international co-operation.

DR. J. L. GREssitT, chairman of the Department of Entomology at the Bishop Museum, Honolulu, has been appointed to the Linus Allen Bishop distinguished chair of zoology by the Trustees of the Museum. This appointment is the first of its kind at the Museum and is in recognition of Dr. Gressitt's contributions to the entomology of the Pacific area and his leadership as a senior member of the scientific staff in developing the Museum's Department of Entomology.

THE fifth international conference on "Coal Science" will be held in Cheltenham during May 28-30. Further information can be obtained from Mr. R. G. J. Kingsmill, National Coal Board, Coal Research Establishment, Stoke Orchard, Cheltenham, Gloucestershire.

A sHORT conference on "Interference and Coherence", under the auspices of the International Commission for Optics and the Australian Academy of Science, will be held in Sydney during September 1-8, 1964. Further information can be obtained from W. H. Steel, Commonwealth Scientific and Industrial Research Organization Division of Physics, City Road, Chippendale, N.S.W.

AN international conference on "Photographic and Spectroscopic Optics", arranged by the Science Council of Japan and the Japan Society of Applied Physics under the auspices of the International Commission for Optics, will be held in Tokyo and Kyoto during September 1-8, 1964. Further information can be obtained from Prof. H. Kubota, ICO-Tokyo and Kyoto, Science Council of Japan, Ueno Park, Tokyo.

THE Golden Jubilee celebrations of the East Malling Research Station will be held during June 25-28. The following aspects of the Station's research work will be demonstrated: laboratories and special exhibits (June $25)$; research on small fruits (June 26); research on top fruits (June 27); research on hops (June 28). Further information can be obtained from the Scientific Liaison Officer, East Malling Research Station, East Malling, Maidstone, Kent.

Erratum. Mr. T. J. Gill (III) has written to the Editor stating that in the communication entitled "Role of Optical Isomers in Determining the Antigenicity of Synthetic Polypeptides", which appeared on p. 746 of the February 23, 1963, issue of Nature, the graph in Fig. 1 at the top of p. 747 should have its ordinate labellod "O.D./ml" instead of " $\mu \mathrm{gAbN} / \mathrm{ml}$ ". 